\title{
A new species of Diomus Mulsant (Coleoptera: Coccinellidae: Diomini) from the eastern Amazon
}

\author{
Albéryca Stephany de Jesus Costa Ramos ${ }^{1}$, Guillermo González², Raimunda \\ Nonata Santos de Lemos ${ }^{1 *}$
}

${ }^{1}$ Universidade Estadual do Maranhão (UEMA), Programa de Pós- Graduação em Agroecologia, São Luís, MA, Brasil.

${ }^{2}$ Sociedad Chilena de Entomologia, Santiago, Chile.

urn:lsid:zoobank.org:act.7B1EFAD4-1D59-4F07-845E-194350BA28B6

\section{A R T I C L E I N F O}

\section{Article history:}

Received 13 February 2020

Accepted 26 September 2020

Available online 30 October 2020

Associate Editor: Rodrigo Feitosa.

\begin{abstract}
A B S T R A C T
A new coccinellid species, Diomus leondai sp. nov. (Coleoptera: Coccinellidae: Diomini) is described from northeast Brazil, São Luis, municipality of Raposa, Cumbique. The specimens collected were found feeding on Phenacoccus solenopsis Tinsley and Phenacoccus sp. on the branches, leaves, and fruits of Abelmoschus esculentus L. Moench, Hibiscus acetosella Welw. ex. Hiern and Hibiscus sabdariffa L. (Malvaceae), and Capsicum spp. and Solanum lycopersicum L. (Solanaceae). Some concepts behind the definition and scope of the genus Diomus and tribe Diomini are analyzed, recognizing the need to better characterize its morphological aspects and establish its composition more precisely.
\end{abstract}

\section{Introduction}

Diomus Mulsant, 1850, is a cosmopolitan genus of small to tiny pubescent coccinellids, whose greatest diversity is found in tropical regions, with some species present in temperate areas. Initially described as a subgenus of Scymnus (Mulsant, 1850), its status was elevated to that of a separate genus by Weise (1895), although this was not recognized by some of the later major works (e.g. Korschefsky, 1931; Blackwelder, 1945). The study of Diomus has been subject to great advances in the last 50 years, including the contributions of Gordon (1976, 1985, 1999), relating to American fauna, and Pang and Ślipiński (2009, 2010), pertaining to the fauna of Australia. These studies have increased the known species number from a few dozens to about 400 today, enhanced the use of genitalia structure in the determination of the species, and improved the systematic analysis of their morphological characters. These authors also undertook the study of the tribe Diomini (erected by Gordon, 1999), attempting to define it and locate numerous related genera within it. Vandenberg and Hanson (2019) reviewed the concepts behind the tribe Diomini and the genus Diomus (further considering Ślipiński, 2007), redefining the scope of the tribe and transferring Erratodiomus Gordon, 1999 and Magnodiomus Gordon,

\footnotetext{
* Corresponding author:

E-mail: rlemos@cca.uema.br (R.N.S. Lemos).
}

1999 to Hyperaspidini: Selvadiina. They also described a striking new phytophagous genus, Moiradiomus Vandenberg and Hanson, and pointed out inconsistencies in the treatment of morphological characters by previous authors, redefining the genera and providing a new world key for Diomini genera.

With the discovery of a new species of the genus from the eastern Amazon, the objective of this work was to describe it and analyze some concepts behind the genus Diomus.

\section{Material and Methods}

Specimens were manually collected in vegetable production areas at the Itapari cluster in São José de Ribamar (02 $\left.50^{\prime} 54^{\prime \prime} \mathrm{S}, 44^{\circ} 02^{\prime} 94^{\prime \prime} \mathrm{W}\right)$, Pindoba in Paço do Lumiar (02 $51^{\prime} \mathrm{S}, 44^{\circ} 09^{\prime} \mathrm{W}$ ), and Cumbique in Raposa (02ํ4' 49" S, 44ํ14' 46” W).

The Coccinellidae material studied is deposited in the Coleção Entomológica Pe. Jesus Santiago Moure, Departamento de Zoologia, Universidade Federal do Paraná, Curitiba (DZUP), and in the Coleção Entomológica Iraci Paiva Coelho in the Universidade Estadual do Maranhão, São Luís (CIPC), where the samples of Pseudococcidae (the prey of the species described here) are also deposited. Samples of the 
plant specimens are deposited in the Herbário Rosa Mochel (SLUI) of the Universidade Estadual do Maranhão.

The identification of Diomus species was performed by the second author based on male genitalia structure, because the color designs, size, and body shape are very similar among species, and the genus lacks other suitable morphological characters for species recognition. The female genitalia are useful in the identification of only a few species, and mainly for discounting species, not identifying them. For genitalia extraction we used the standard procedure as described in Vandenberg and Hanson (2019). Following this, the abdomen was washed with distilled water and the genital structures were dissected with pins. The dissected parts were examined using an optical microscope, photographed, and finally packed in microvials with glycerin, together with the respective specimen. Genus determination was performed using the keys and descriptions in Gordon (1999) and Vandenberg and Hanson (2019). Species determination was performed using the keys in Gordon (1999) and revision of other South American species described in later papers (González and Honour, 2011; González, 2015, 2016). The group classification of Gordon (1999) for South American species was used, considering the large number of species involved in Diomus, and recognizing, as Gordon (1999) stated and Vandenberg and Hanson (2019) noticed, that some groups are probably paraphyletic; these were used only for identification purposes. Paratypes included only the specimens with extracted genitalia, considering that there are a sufficient number of specimens and this method produces more accurate results than using only external characters for identification. The rest of the specimens are indicated as "additional material". Plant specimens were identified by Dr. José Ribamar Gusmão Araújo of the Universidade Estadual do Maranhão (UEMA), and the Pseudococcidae specimens by Dra. Ana Lúcia Benfatti Gonzalez Peronti of Faculdade de Ciências Agrárias e Veterinárias (FCAV-UNESP). Coccinellidae terminology follows Ślipiński (2007), except for certain characters not specified by this author (e.g. penis capsule arms, penis guide teeth, etc.), which follow Gordon (1999). The labels attached to the specimens examined were transferred literally in quotation marks (“”), and the lines separated by oblique bars $(/)$.

\section{Systematics}

\section{Diomus Mulsant, 1850.}

Diomus is the Coccinellidae genus that presents the largest number of species in South America. It is composed of 261 species in the subcontinent, discounting some species included in Gordon (1999) but restricted to the Caribbean (Trinidad Island); 133 of them have been recorded occurring in Brazil (Gordon, 1999; González and Honour, 2011; González 2016). Vandenberg and Hanson (2019) did a detailed historical review for both Diomus and the tribe Diomini, remarking on the composition of the genus and analyzing some historical misinterpretations of its morphology, including the antennomeres (11 for South American Diomus species and 10 for some Australian species), the tarsomeres (3), the ocular canthus, interfacetal setae, and coxite stylus (normally present). These authors concluded that Diomus is possibly polyphyletic, and that as knowledge of the group progresses, their lineages will be better identified, perhaps with the help of molecular analysis. Our sampling confirmed these characters in South American species, including the new species described below. Diomus is defined morphologically by the descending postcoxal lines (Fig. 1h), prosternum with emarginated anterior border ("Y" shaped), trimerous tarsus, short antennae with 11 antennomeres, terminal maxillary palpomere securiform, abdomen with 6 ventrites, genital apparatus of the male with asymmetric penis guide, and typical female coxites short and transverse (Gordon, 1999; Vandenberg and Hanson, 2019).

\section{Biological and trophic relations}

Biological information about species of the genus Diomus is scarce. Their prey (Gordon 1999) include aphids, mealybugs, scale insects, and whiteflies, with a distinct feeding preference for the family Pseudococcidae. Records from South America of Pseudococcidae are: Phenacoccus herreni Cox and Williams, 1981 with Diomus sixtus Gordon, 1999 and D. susanna Gordon, 1999; Phenacoccus madeirensis Green, 1923 with D. anselm Gordon, 1999 and D. stephen Gordon, 1999; Phenacoccus manihoti Matile-Ferrero, 1977 with D. clare Gordon, 1999, D. hennessyi Fürsch, 1987 and D. irenaeus Gordon, 1999; Planococcus citri(Risso, 1813) with D. robert Gordon, 1999 and D. romanus Gordon, 1999 (Gordon, 1999). They are also associated with Monophlebidae: Crypticerya multicicatrices Kondo and Unruh, 2009 with Diomus sp. (Kondo et al., 2012) and D. seminulus (Mulsant, 1850) (González et al., 2012). There are also cases of Myrmecophilia; D. thoracicus Fabricius, 1801 (the genus type species) found in French Guiana in close association with Wasmannia auropunctata(Roger, 1863)(Hymenoptera: Formicidae), inhabiting its nest and feeding on the ant brood (Vantaux et al., 2010). In South America D. lupusapudoves Vandenberg, Iverson and Liere, 2018 was found feeding on Coccus viridis (Green, 1889) (Coccidae) in crops of coffee in Chiapas, Mexico, protected by Azteca sericeasurLongino, 2007 and Pheidole synanthropica Longino, 2009 (Hymenoptera: Formicidae) (Vandenberg et al., 2018).

\section{Diomus leondai González, Ramos and Lemos sp. nov.}

(Fig. 1a-s).

Diagnosis: Diomus leondai sp. nov. presents a very common design, shared with various species of the genus, consisting of lightcolored elytra with a dark border covering the base, suture, and part of the lateral border (Fig. 1a). It is distinguished from other Diomus species by the male genitalia, which agree with Gordon's "F" group, primarily distinguished by having a long apical penis flagellum at least one-quarter the length of the penis (Fig. 10), parameres without apical modifications, and a basal lobe lacking a ventral membranous appendage (Fig. 1k, 1n) (Gordon 1999). In this group D. leondaican be distinguished by a penis guide with sclerotized apical teeth (Fig. 1j), without dorsal keel (Fig. 1n) and with a median clump of setae (Fig. 11), a combination of characters not known for any other species in the group.

Description: Holotype male. Length: $1.5 \mathrm{~mm}$. Width: $1.1 \mathrm{~mm}$. Oval shape with maximum width at two-fifths of elytra length, with thin dorsal punctuation and yellow-colored dorsal pilosity (Fig. 1a). Head shiny, yellowish-brown, finely punctured, punctures separated by about twice a diameter, frons slightly narrowed from vertex to clypeus, about 2.5 times eye width, mouthparts and antennae yellow (Fig. 1c), apical maxillary palpomere securiform, antennae with 11 antennomeres. Pronotum yellowish brown, slightly dark reddish around the center of the base (Figs. 1a, 1c), with punctures larger than on head, separated by little more than a diameter. Scutellum semicircular, reddish brown, bordered with dark brown. Elytra yellow, with broad basal border, lateral borders and triangular scutellar area dark brown, scutellar area extending posteriorly along the suture to apical declivity, narrowing from base to apex, lateral border extending posteriorly on lateral margin to apical twothirds (Figs. 1a, 1d-e), punctures smaller than the pronotal punctures, separated by about twice a diameter. Ventral side yellowish-brown with dark brown pro-, meso-, and metasternum (Fig. 1b). Prosternum "Y" shaped, apically emarginated, with prosternal carina extended to the apex. Metasternum postcoxal line complete, descending in semicircular curve, ending in lateral border two-fifths from base of length of sternum. Legs yellow (Fig. 1c), with tarsi trimerous. Abdomen yellowish brown 

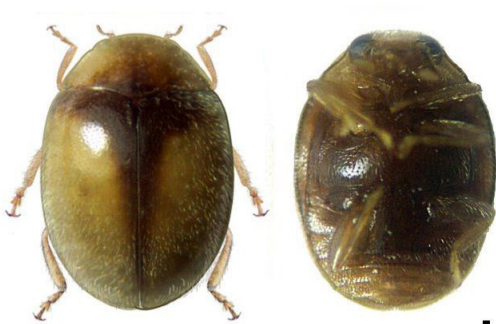

a

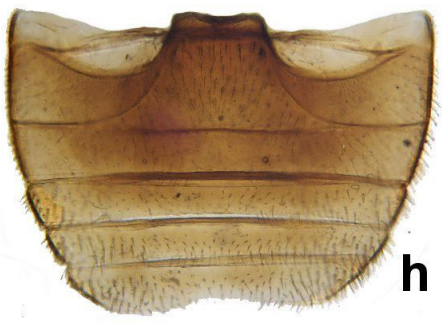

b

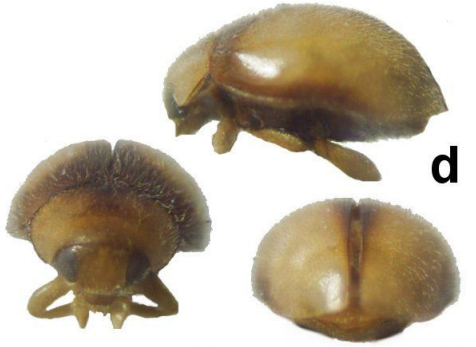

C

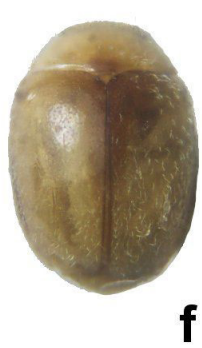

e

f

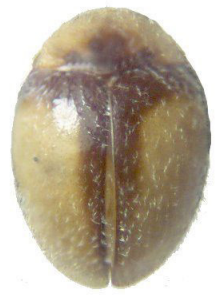

g
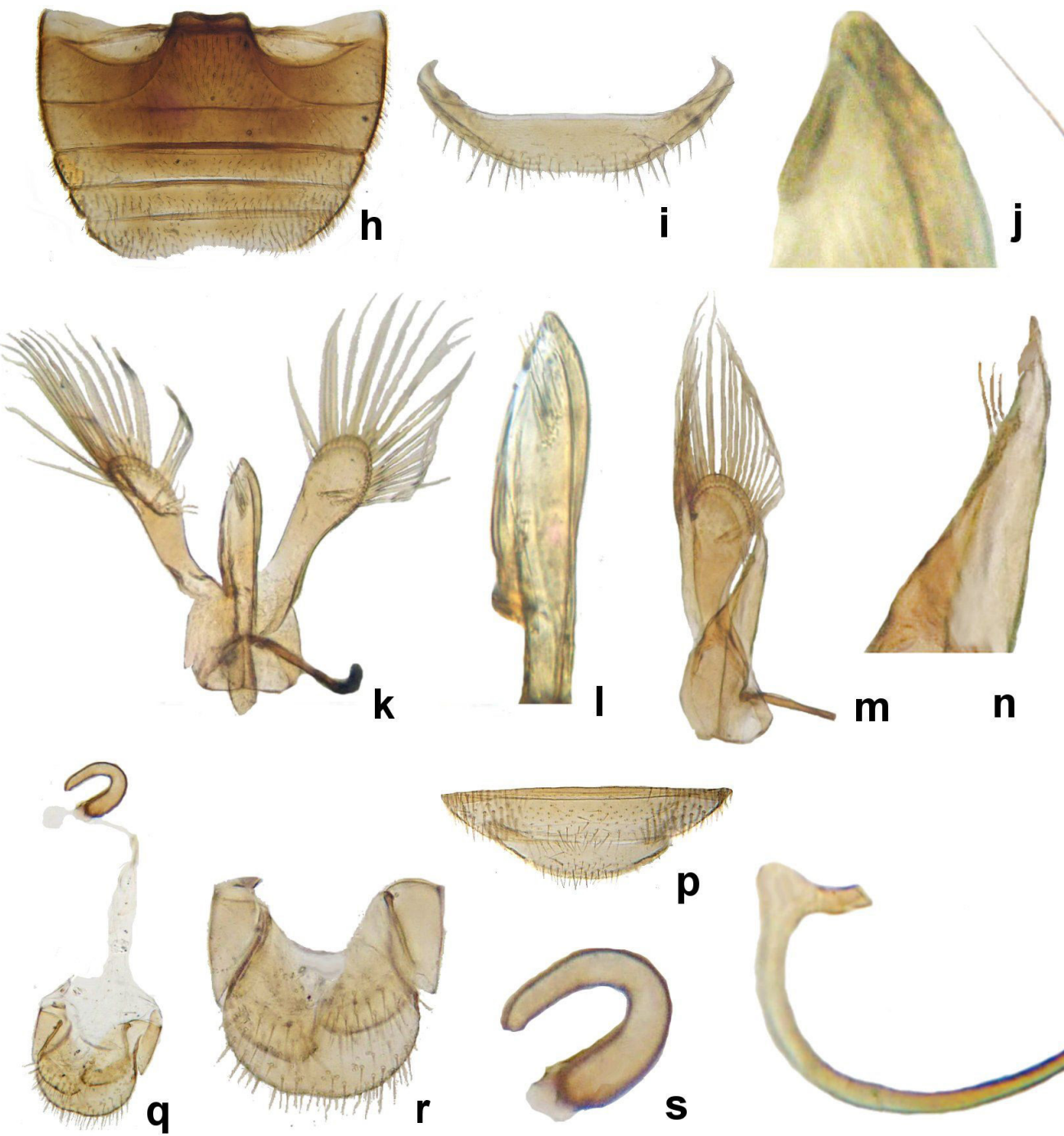

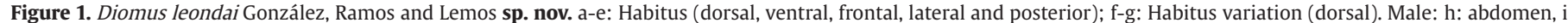

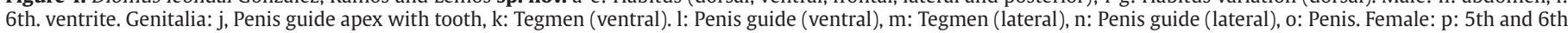
ventrites, q: genital apparatus, r: Terminalia with coxites, s: Spermatheca.

with the middle part of the first two ventrites dark brown (Fig. 1b), with 6 ventrites, postcoxal line of first ventrite extending in curve to the hind margin of ventrite. Male genitalia with tegmen with sub-square phallobase (Fig. 1k) and penis guide with almost parallel sides in ventral view, triangular with convex edges in apical one-third, with sclerotized apical teeth (Fig. 11); in lateral view it is triangular, pointed apically with clump of dorsal setae, dorsal keel absent (Fig. 1n). Parameres exceeding penis guide by one-third, widened from base to rounded apex (Fig. 1k). Penis curved in basal three-quarters, sinuate near apex, with thin flagellum projecting along half penis length; penis capsule with slightly concave basal margin, reduced triangular outer arm, inner arm well-developed, perpendicular to the body, twice long as wide (Fig. 10). Apex of 5th ventrite deeply emarginated medially (Fig. 1h), 6th ventrite apex medially truncate (Fig. 1i).

Female: Habitus and variations similar to male, genitalia (Fig. 1q) with C-shaped spermatheca, broad at the base and narrowing toward the apex, ramus beaked (Fig. 1s), coxites short, somewhat transverse, bearing styli (Fig. 1r), 5th ventrite apex slightly truncate, 6th ventrite apically arcuate (Fig. 1s). 
Variation: Length: $1.2-1.5 \mathrm{~mm}$. Width: $0.9-1.1 \mathrm{~mm}$. Pronotum varying from indicated to a large dark brown basomedian spot, emarginated in lateral margins (Fig. 1g). The dark elytral margins variable in extension, the color sometimes light brown and diffuse or may be missing, leaving only a reddish-yellow scutellar spot (Fig. 1f).

Type material: Holotype male: "BRASIL, MA [State of Maranhão], São José de Ribamar $\backslash\left[02^{\circ} 50^{\prime} \mathrm{S}, 44^{\circ} 02^{\prime} \mathrm{W}\right] \mid$ Em Hibiscus sabdariffa A.S.J.C. Ramos, ix.2016” “CIPC |Ref. 755-75” (DZUP). Paratypes: 12 females and 2 males: 3 females: same data as holotype (DZUP); 5 females and 1 male: "BRASIL, MA [State of Maranhão], Raposa| [02 $\left.{ }^{\circ} 46^{\prime} \mathrm{S}, 44^{\circ} 14^{\prime} \mathrm{W}\right] \mid$ on Hibiscus acetosella\A.S.J.C. Ramos, xi.2016" "CIPC |Ref. 757-121" (DZUP); 4 females: same data as preceding (DZUP); 1 male "BRASIL, MA [State of Maranhão], Paço do Lumiar [02 51 'S, $\left.44^{\circ} 09^{\prime} \mathrm{W}\right] \backslash$ Em Hibiscus sabdariffa $\mid$ A.S.J.C. Ramos, x.2017" "CIPC । Ref. 824 -84" (DZUP). All type material with extracted genitalia in microvials. Additional material: 54 specimens: 3 specimens: "BRASIL, MA [State of Maranhão], São José Ribamar [02 $\left.{ }^{\circ} 50^{\prime} S, 44^{\circ} 02^{\prime} \mathrm{W}\right] \backslash \mathrm{Em}$ Hibiscus sabdariffa $\mid$ A.S.J.C. Ramos, vi.2017" "CIPC \ Ref. 822-400"; 3 specimens: same data as preceding; 7 specimens: same data as preceding except "ix.2016" and "Ref. 823-69"; 1 specimen: same data as preceding except "ii.2018" and "Ref. 856-422"; 1 specimen: same data as preceding except "x.2017" and "Ref. 832-263"; 2 specimens: “BRASIL, MA [State of Maranhão], São José Ribamar [02 50 'S, $44^{\circ} 02^{\prime} \mathrm{W}$ ] $\backslash$ Em Phenacoccus solenopsis $\backslash$ em Hibiscus sabdariffa $\backslash$ A.S.J.C. Ramos, xi.2017" "CIPC | Ref. 828-402"; 1 specimen: "BRASIL, MA [State of Maranhão], Raposa [02 $\left.46^{\prime} \mathrm{S}, 4^{\circ} 14^{\prime} \mathrm{W}\right] \backslash$ Em Hibiscus sabdariffa A.S.J.C. Ramos, xi.2016” "CIPC \Ref. 821-122”; 2 specimens: same data as preceding except "xi.2016" and "Ref. 825-111"; 1 specimen: same data as preceding except "x.2017" and "Ref. 829-274"; 2 specimens: same data as preceding except "Ref. 830-272"; 3 specimens: "BRASIL, MA [State of Maranhão], São José Ribamar [02 $\left.{ }^{\circ} 50^{\prime} S, 44^{\circ} 02^{\prime} \mathrm{W}\right] \backslash$ Em Solanum lycopersicum \A.S.J.C. Ramos, x.2017" "CIPC \Ref. 797-88"; 1 specimen: same data as preceding except "iv.2017" and "Ref. 796182"; 3 specimens: same data as preceding except "xii.2016" and "Ref. 833-149"; 15 specimens: same data as preceding; 1 specimen: “BRASIL, MA [State of Maranhão], Raposa [02 $46^{\prime}$ S, $\left.44^{\circ} 14^{\prime} \mathrm{W}\right] \backslash \mathrm{Em}$ Abelmoschus esculentus $\backslash$ A.S.J.C. Ramos, v.2018” "CIPC \Ref. 751378"; 4 specimens: same data as preceding except "xi.2016" and "Ref. 811-124"; 1 specimen: "BRASIL, MA [State of Maranhão], Paço do Lumiar [02 $\left.{ }^{\circ} 51^{\prime} \mathrm{S}, 44^{\circ} 09^{\prime} \mathrm{W}\right] \backslash$ Em Abelmoschus esculentus $\backslash$ A.S.J.C. Ramos, xi.2016" “CIPC | Ref. 756-117"; 1 specimen: "BRASIL, MA [State of Maranhão], Raposa [02 $\left.{ }^{\circ} 46^{\prime} \mathrm{S}, 44^{\circ} 14^{\prime} \mathrm{W}\right] \backslash$ Em Capsicum spp.| A.S.J.C. Ramos, v.2017" “CIPC \Ref. 804-194"; 1 specimen: same data as preceding; 1 specimen: "BRASIL, MA [State of Maranhão], Paço do Lumiar [0251'S, 44 09'W] Em Capsicum spp.|A.S.J.C. Ramos, ix.2016” "CIPC \Ref. 805-232" (CIPC).

Biology: Specimens were collected on the branches, leaves, and fruits of Abelmoschus esculentus L. Moench, Hibiscus acetosella Welw. Ex Hiern, Hibiscus sabdariffa L. (Malvaceae), Capsicum spp., and Solanum lycopersicum L. (Solanaceae). The specimens were observed feeding on Phenacoccus solenopsis Tinsley, 1898 and Phenacoccus sp.

Etymology: The name of the species is a reference to the first author's grandfather. Leonda is the nickname of Leônidas.

Discussion: Diomus leondai n. sp. presents the typical characteristics of the genus mentioned above (see Diomus Mulsant, 1850). It also presents the characters typical of group "F" of Gordon (see diagnosis). It has the remarkable condition of having a lateral tooth at the apex of the tegmen (Fig. $1 \mathrm{j}$ ), a condition that is common in group " $\mathrm{C}$ " of Gordon, but very rare in group " $\mathrm{F}$ ", being present in only two other species, $D$. sylvester Gordon from Venezuela and $D$. soter Gordon, 1999, from Pernambuco, Brazil; the latter presents 2 apical teeth (Gordon, 1999). The combination of a clump of dorsal setae in the basal lobe (Fig. 11), together with the absence of dorsal keel (Fig. 11) is also a very rare combination, being present only in $D$. sussane Gordon, 1999 from Pernambuco, Brazil and D. symphorosa Gordon, 1999 from Colombia.

The description of a new species of Diomus increases the number of species for this genus in South America to 262. The persistent increase of new species of the genus during the last decade (González and Honour, 2011; González, 2015, 2016), based on the review of very restricted material, points out that there could still be many species to discover. The geographic distribution of most South American species is barely known; as an example, about 140 species described by Gordon (1999) are known only from the type locality; the vast majority have a single specimen.

The work of Gordon (1999), with images and detailed descriptions of the genitalia of species and their distribution in groups (although not necessarily monophyletic) has been of great help in recognizing the species described. The absence of specialists in taxonomy has been a major obstacle for the genus to be better known.

The exploration of new regions and the study of existing collections will allow for the discovery of new species and improve the knowledge of the distribution of those already described. There is an almost universal ignorance of the biology of these species; notable are the contributions to myrmecophilous species (Vantaux et al., 2010; Vandenberg et al., 2018), but these are atypical species, and knowledge of the rest of the species that feed mainly on Pseudococcidae is reduced almost exclusively to a few records of prey taken from the labels.

Although in South America the genus appears quite well defined and homogeneous, Vandenberg and Hanson (2019) noted that Australian species cannot be assigned to any of the groups defined for South America (Gordon, 1999) and pointed out the need to continue investigating the morphological aspects of the genus globally, and develop molecular studies to discern problems not yet resolved. It should be noted that the genera present in the tribe Diomini appear well-differentiated and defined (Vandenberg and Hanson, 2019).

A phylogenetic analysis that considers feed, as well as morphological, molecular, and biogeographic characteristics could find that some of these genera only constitute secondary branches of the genus Diomus, (and therefore do not justify their generic category), or that Diomus, in turn, has separate lineages that deserve to be considered genera by themselves. This study is pending.

\section{Acknowledgments}

The authors thank the anonymous reviewers, who contributed greatly to improving and correcting this work. This work was supported by FAPEMA (Foundation for Research Support and Scientific and Technological Development of Maranhão - Process UNIVERSAL-01327/18).

\section{Conflicts of interest}

The authors declare no conflicts of interest.

\section{Author contribution statement}

AC carried out the field work, including the collection of specimens, GG carried out the taxonomic work, dissections, photographs and the preparation of plates, AC and GG wrote the initial manuscript, AC, GG and RL participated in the corrections and final redaction. 


\section{References}

Blackwelder, R. E., 1945. Checklist of the Coleopterous Insects of Mexico, Central America, the West Indies, and South America, Part. 3. U. S. Nat. Mus. Bull. 185, 343-550.

González, G., 2015. Especies nuevas y nuevos registros de coccinélidos (Coleoptera: Coccinellidae) de Ecuador. Bol. SEA 57, 143-163.

González, G., 2016. Descripción de 11 especies nuevas del género Diomus Mulsant (Coleoptera: Coccinellidae: Diomini) de América del Sur y nuevos registros para Brasil, Colombia, Ecuador y Perú. Bol. SEA 59, 47-63.

González, G., Honour, R., 2011. Especies nuevas del género Diomus Mulsant (Coleoptera, Coccinellidae) de América del Sur. Bol. SEA 49, 1-14.

González, G., López, R., Kondo, T., 2012. First report of Delphastus quinculus Gordon and Diomus seminulus (Mulsant) (Coleoptera: Coccinellidae) feeding on eggs and first-instar nymphs of Crypticerya multicicatrices Kondo and Unruh (Hemiptera: Monophlebidae). Insecta Mundi 0268, 1-6.

Gordon, R. D., 1976. The Scymnini of the United States and Canada: key to genera and revision of Scymnus, Nephus and Diomus. Bull. Buffalo Soc. Nat. Sci. 28, 1-362.

Gordon, R. D., 1985. The Coccinellidae (Coleoptera) of America north of Mexico. J. N.Y. Entomol. Soc. 93, 1-912.

Gordon, R. D., 1999. South American Coccinellidae (Coleoptera). Part VI: a systematic revision of the South American Diomini, new tribu (Scymninae). Ann. Zool. 49, 1-219.

Kondo, T., Gullan, P. J., Ramos Portilla, A. A., 2012. Report of new invasive scale insects (Hemiptera: Coccoidea), Crypticerya multicicatrices Kondo and Unruh (Monophlebidae) and Maconellicoccus hirsutus
(Green) (Pseudococcidae), on the islands of San Andres and Providencia, Colombia. Insecta Mundi 0265, 1-17.

Korschefsky, R., 1931. Coleopterorum Catalogus, pars 118 Coccinellidae, I. W Junk, Schenklink.

Mulsant, E., 1850. Species de Coleóptères Trimères Sécuripalpes. Maison, Paris, Lyón.

Pang, H., Ślipiński, A., 2009. Revision of the Australian Coccinellidae (Coleoptera). Genus Diomus Mulsant. Parte 1. Ann. Zool. 59, 641698. https://doi.org/10.3161/000345409X485008.

Pang, H., Ślipiński, A., 2010. Revision of the Australian Coccinellidae (Coleoptera). Genus Diomus Mulsant. Parte 2. Ann. Zool. 60, 645702. https://doi.org/10.3161/000345410X550382.

Ślipiński, A., 2007. Australian Ladybird Beetles (Coleoptera: Coccinellidae). Their Biology and Classification. ABRS, Canberra.

Vandenberg, N. J., Hanson, P. E., 2019. Overview of the lady beetle tribe Diomini (Coleoptera: Coccinellidae) and description of a new phytophagous, silk-spinning genus from Costa Rica that induces food bodies on leaves of Piper (Piperaceae). Zootaxa 4554, 255-285.

Vandenberg, N. J., Iverson, A., Liere, H., 2018. A new species of myrmecophilous lady beetle in the genus Diomus (Coleoptera: Coccinellidae: Diomini) from Chiapas, Mexico that feeds on green coffee scale, Coccus viridis (Green) (Hemiptera: Coccidae). Zootaxa 4420, 113-122. https://doi.org/10.11646/zootaxa.4420.1.6.

Vantaux, A., Roux, O., Magro, A., Ghomsi, N. T., Gordon, R. D., Dejean, A., Orivel, J., 2010. Host-specific myrmecophily and myrmecophagy in the tropical coccinellid Diomus thoracicus in French Guiana. Biotropica 42, 622-629. https://doi.org/10.1111/j.1744-7429.2009.00614.x.

Weise, J., 1895. Neue Coccinelliden, sowie Bekermungen zu Bemerkungen zu bekannten Arten. Ann. Soc. Ent. Belg. 39, 120-146. 